INEL-94/0237

\title{
Clean Lead Facility Inventory System User's Manual
}

\author{
J. F. Garcia \\ Published December 1994 \\ Idaho National Engineering Laboratory \\ Lockheed Idaho Technologies Company \\ Idaho Falls, Idaho 83415
}

Prepared for the

U.S. Department of Energy

Under DOE Idaho Field Office

Contact DE-AC07-94ID13223 



\section{DISCLAIMER}

Portions of this document may be illegible electronic image products. Images are produced from the best available original document. 


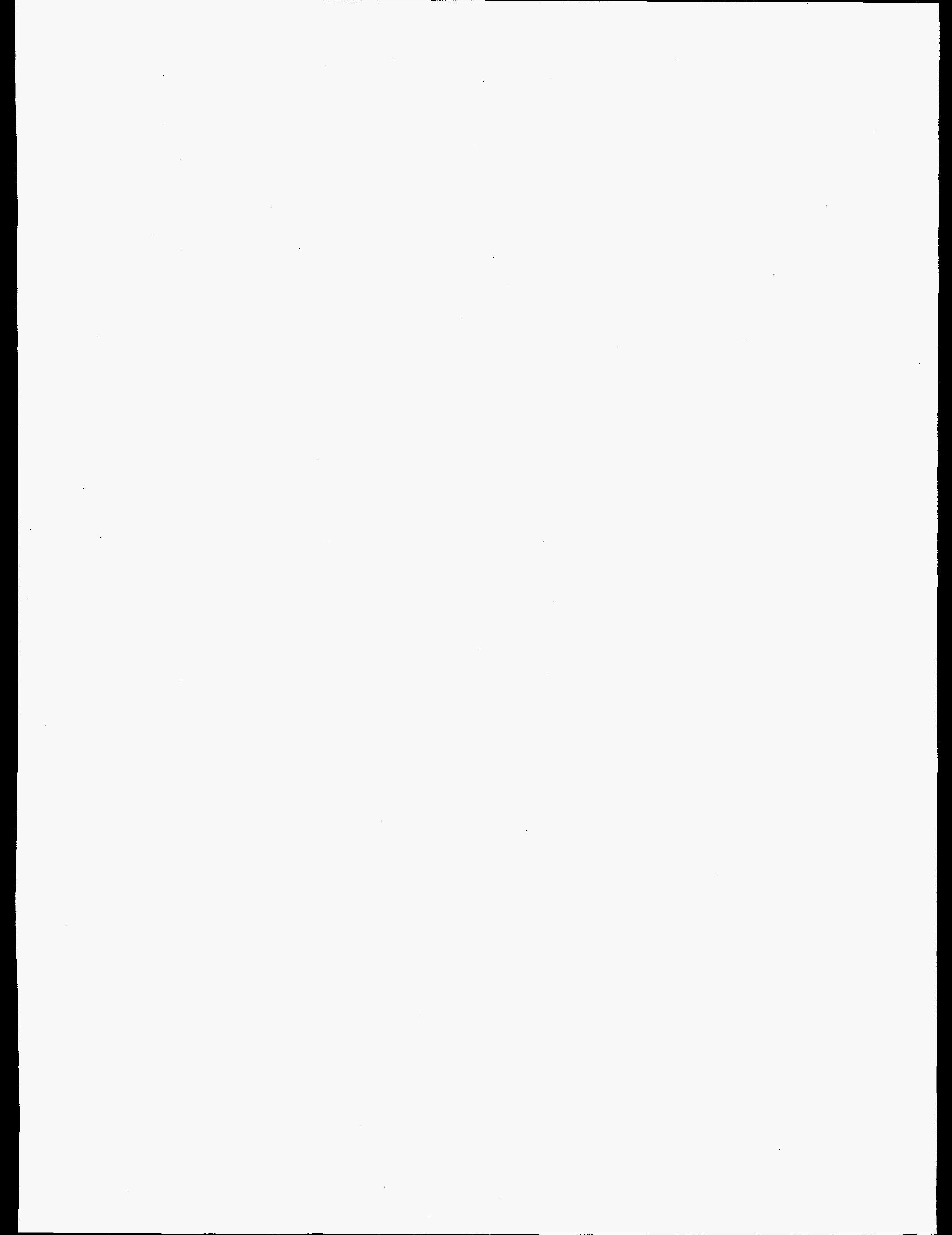




\begin{abstract}
The purpose of this user's manual is to provide instruction and guidance needed to enter and maintain inventory information for the Clean Lead Facility (CLF), PER-612. Individuals responsible for maintaining and using the system should study and understand the information provided. The user's manual describes how to properly use and maintain the CLF Inventory System. Annual, quarterly, monthly, and current inventory reports may be printed from the Inventory System for reporting purposes. Profile reports of each shipment of lead may also be printed for verification and documentation of lead transactions. The CLF Inventory System was designed on Microsoft Access version 2.0.

Similar inventory systems are in use at the Idaho National Engineering Laboratory (INEL) to facilitate site-wide compilations of mixed waste data. The CLF Inventory System was designed for inventorying the clean or non-radioactive contaminated lead stored at the CLF. This data, along with the mixed waste data, will be compiled into the Idaho Mixed Waste Information (IMWI) system for reporting to the Department of Energy - Idaho Office, Department of Energy - Headquarters, and/or the State of Idaho.
\end{abstract}

\title{
DISCLAIMER
}

This report was prepared as an account of work sponsored by an agency of the United States Government. Neither the United States Government nor any agency thereof, nor any of their employees, makes any warranty, express or implied, or assumes any legal liability or responsibility for the accuracy, completeness, or usefulness of any information, apparatus, product, or process disclosed, or represents that its use would not infringe privately owned rights. Reference herein to any specific commercial product, process, or service by trade name, trademark, manufacturer, or otherwise does not necessarily constitute or imply its endorsement, recommendation, or favoring by the United States Government or any agency thereof. The views and opinions of authors expressed herein do not necessarily state or reflect those of the United States Government or any agency thereof. 
INEL-94/0237

Rev. 0

\section{Clean Lead Facility Inventory System \\ User's Manual}

\section{Approval:}

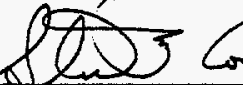

Waste Reduction Operations Complex Supervisor (S. B. Rose)

Lead Progam Projegt Manager (E. M. Feldman)

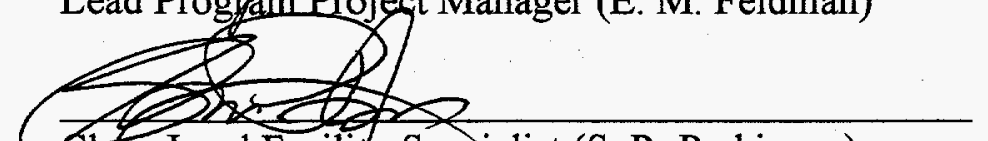

Etean Lead Facilify Specialist (S. R. Parkinson) 


\section{CONTENTS}

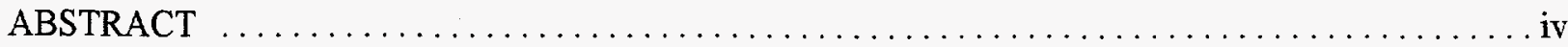

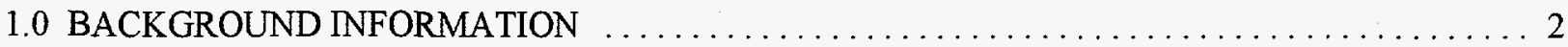

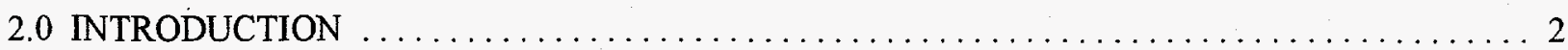

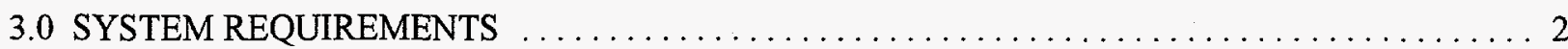

4.0 ACCESSING THE INVENTORY SYSTEM $\ldots \ldots \ldots \ldots \ldots \ldots \ldots \ldots \ldots \ldots \ldots \ldots \ldots \ldots \ldots$

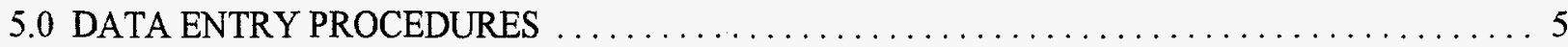

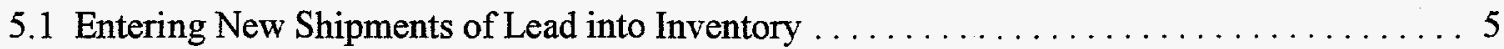

5.2 Entering New Shipments of Lead Leaving the Facility $\ldots \ldots \ldots \ldots \ldots \ldots \ldots \ldots$

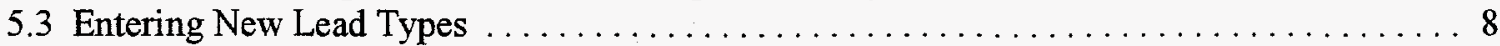

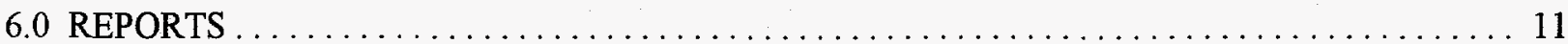

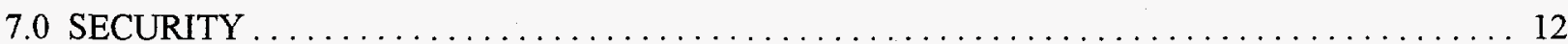

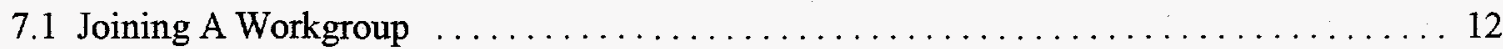

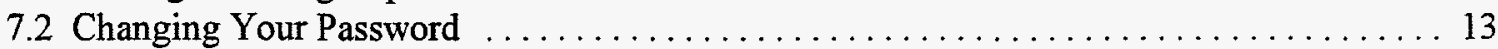

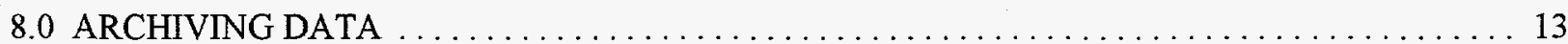

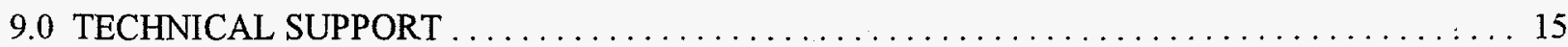

9.1 Troubleshooting and Resolving Inventory Discrepancies $\ldots \ldots \ldots \ldots \ldots \ldots \ldots \ldots$

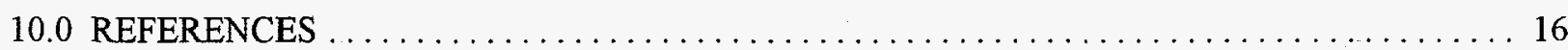

APPENDIX A: DATA STRUCTURE OF THE INVENTORY SYSTEM $\ldots \ldots \ldots \ldots \ldots \ldots \ldots$ A-1

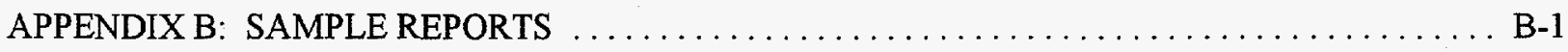

APPENDIX C: UNIQUELY IDENTIFYING LEAD TYPES $\ldots \ldots \ldots \ldots \ldots \ldots \ldots \ldots \ldots \ldots$ C-1

APPENDIX D: CREATING CUSTOM QUERIES AND REPORTS $\ldots \ldots \ldots \ldots \ldots \ldots \ldots \ldots \ldots$ D-1

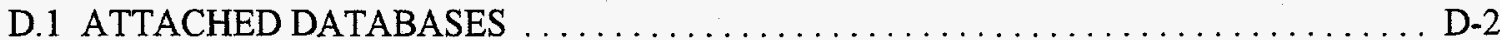

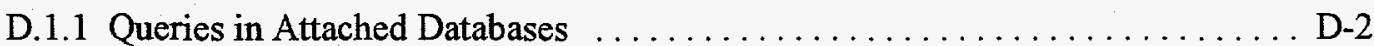

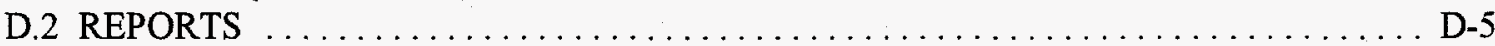

D.2.1 Creating a Report Using Report Wizard $\ldots \ldots \ldots \ldots \ldots \ldots \ldots \ldots \ldots$ D-5

D.2.2 Creating a Report in Design View $\ldots \ldots \ldots \ldots \ldots \ldots \ldots \ldots \ldots \ldots \ldots \ldots \ldots \ldots$ 


\section{FIGURES}

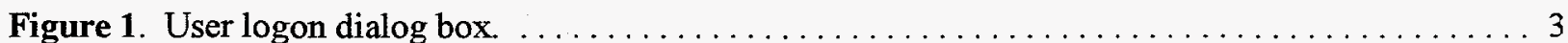

Figure 2. Clean Lead Facility Main Switchboard Screen $\ldots \ldots \ldots \ldots \ldots \ldots \ldots \ldots \ldots \ldots \ldots \ldots 4$

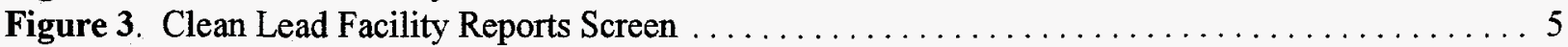

Figure 4. Clean Lead Facility Receiving $\log$ Screen $\ldots \ldots \ldots \ldots \ldots \ldots \ldots \ldots \ldots \ldots \ldots \ldots \ldots \ldots \ldots$

Figure 5. Clean Lead Facility Shipping Log Screen $\ldots \ldots \ldots \ldots \ldots \ldots \ldots \ldots \ldots \ldots \ldots \ldots$

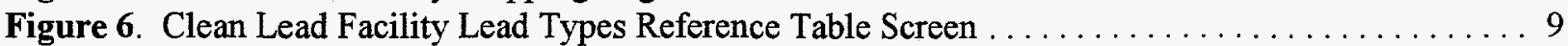

Figure 7. Clean Lead Facility Lead Types Entry Form Screen $\ldots \ldots \ldots \ldots \ldots \ldots \ldots \ldots \ldots$ 


\section{Important Guidelines tor Users.}

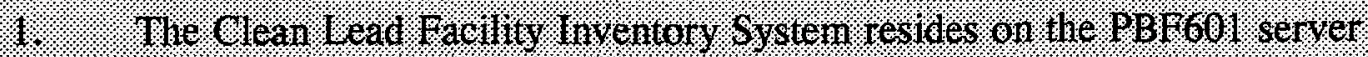

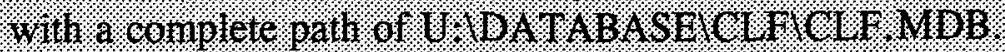

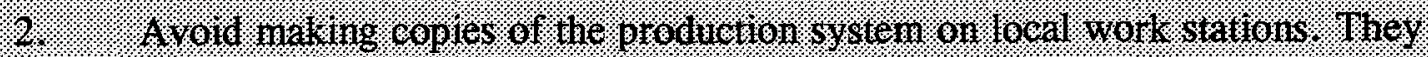

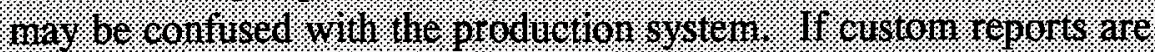

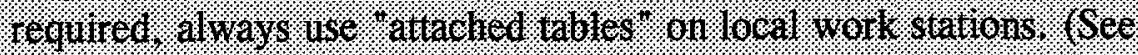

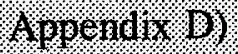

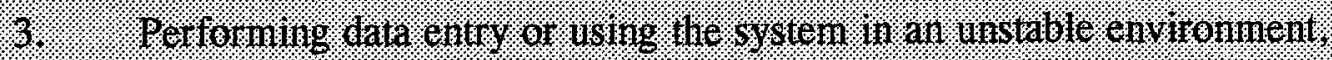

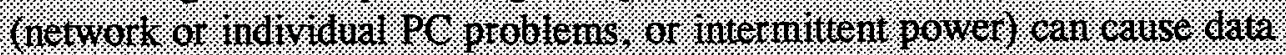
10011011011.

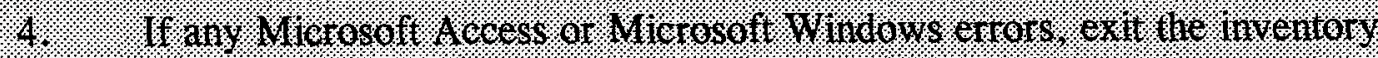

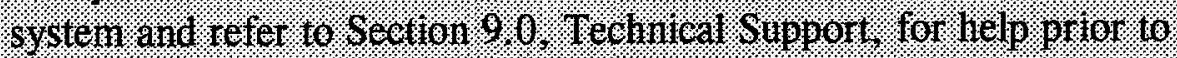

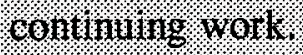

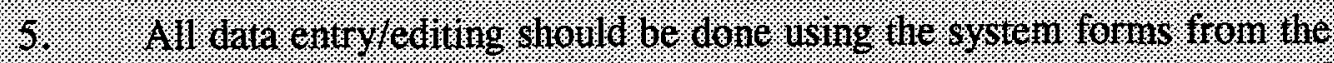

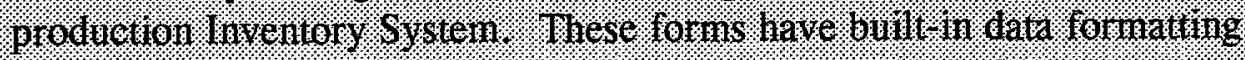

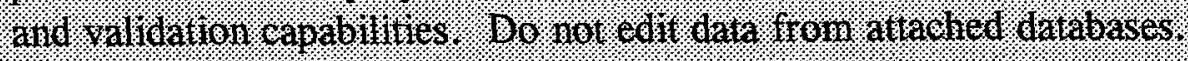

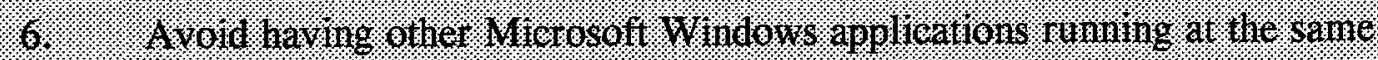

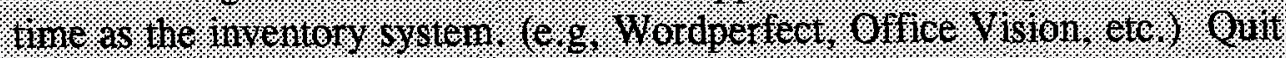

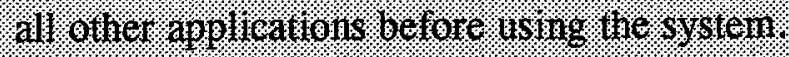

\section{Important Gudelines tor the System Administrator}

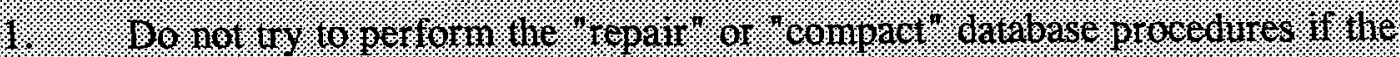

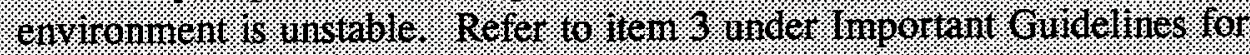

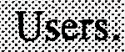

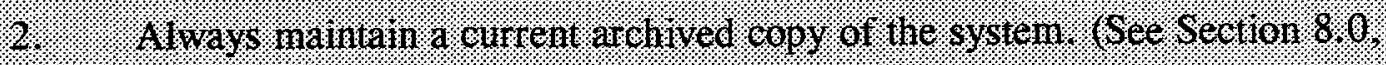


INEL-94/0237

Rev. 0

\subsection{BACKGROUND INFORMATION}

Requirements for lead acceptance at the Clean Lead Facility (CLF) can be found in the Idaho National Engineering Laboratory (INEL) Reusable Property, Recyclable Materials, and Waste Acceptance Criteria (RRWAC) section 4.1.1 and 4.1.6. Although the RRWAC does not explicitly declare that lead coming into storage at the CLF needs to be inventoried, it states that the property must be accurately identified. To ensure that inventory systems are accurate, an actual count of each lead item should be implemented. Additionally, the data needs to be maintained in a manner that allows reporting to be performed. The CLF database was designed to provide a means to count the lead types in inventory and provide reporting capabilities. Since the CLF database relies on the accurate count and identification of each lead type, the personnel sending lead to and shipping lead from the CLF need to be instructed to provide an accurate count of each lead type.

\subsection{INTRODUCTION}

The user's manual provides the operating instructions needed to enter and maintain inventory information for the CLF. It is intended as a reference and a guide only. Data entry procedures, reporting functions, archiving data and ad hoc reporting instructions are discussed in this document. Individuals responsible for maintaining and using the system should study and understand the information provided. Additional information and operating instructions may be obtained by contacting one of the technical advisors identified in Section 9.0.

The user's manual may be used to produce additional or supplemental procedures or directives. Any existing facility specific procedures take precedence over this users manual. The user should be aware of facility and company level procedures that govern the control and use of clean lead.

\subsection{SYSTEM REQUIREMENTS}

For optimum performance of the inventory system, the following system configuration is recommended:

$\begin{array}{ll}- & \text { IBM } 386 \text { or } 486 \text { Computer (486 Preferred) } \\ \text { - } & \text { Minimum 4 Megabytes RAM (8 Megabytes Preferred) } \\ \text { - } & \text { Microsoft Windows version 3.1 } \\ \text { - } & \text { Microsoft Access version 2.0 } \\ \text { - } & \text { Microsoft DOS version } 6.2 \text { or PC DOS Version } 6.3 \\ \text { - } & \text { 20 Megabytes free hard disk space } \\ & \text { Laserjet III or IV printer }\end{array}$




\subsection{ACCESSING THE INVENTORY SYSTEM}

In order to access the inventory system, open the Microsoft (MS) Access 2.0 program group in the Windows program manager then open the MS Access program through normal Windows options (e.g. double click or pull down menus). When you are prompted for a User ID or NAME and PASSWORD as shown in Figure 1, enter the correct information. You will be supplied with a default password when you first receive your User ID. You can change your password at any time in the future once you have entered the database. Instructions for changing the password are contained in Section 7.0, Security.

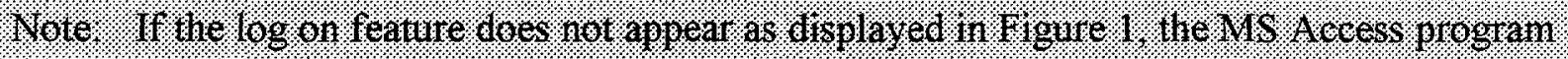
on the PC is not connected to the appropriate workgroup Refert to Section 7.0. Secunty of information on foining a Wortigrout

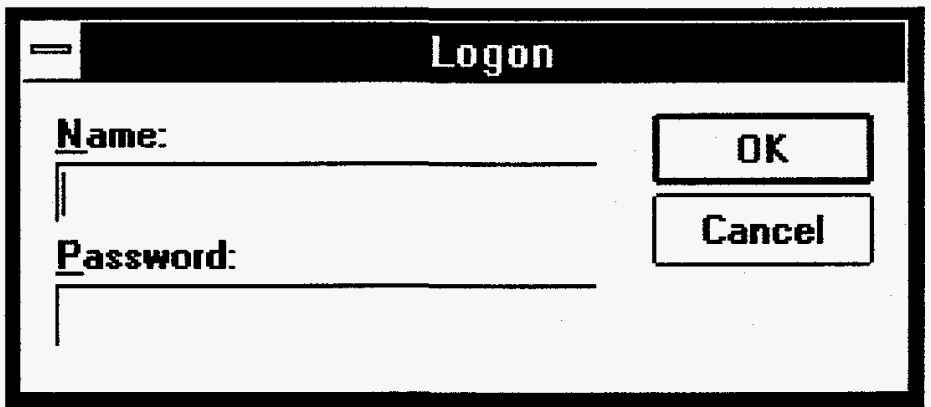

Figure 1. User logon dialog box.

Once the appropriate User ID and Password are entered, the CLF Inventory System database must be opened. The database may be opened by using OPEN from the FILE menu. The complete path is ??? If the database has been opened before then the file may be listed at the bottom of the FILE menu. Selecting the file from the choices listed will open the database.

Upon entering the Inventory System, the Main screen as shown in Figure 2 will appear. The buttons on this screen allow the user to go to the Receiving screen, Shipping screen, Lead Types screen, the Reports screen, or Quit the inventory system. The FILE menu bar may be used in lieu of the buttons. 


\begin{tabular}{l|c|c|c}
\hline & Microsoft Access - [MWSF Inventory System] & - \\
\hline$\square$ & File Security About & $\leftarrow$ \\
\hline
\end{tabular}

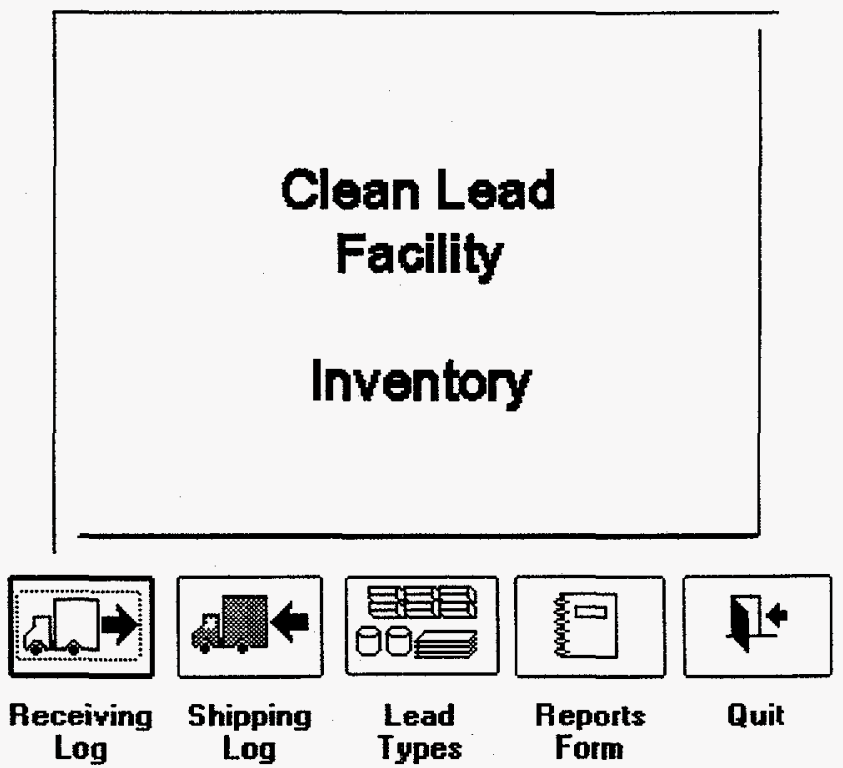

Press to Go to the CLF Receiving Log.

NUM

Figure 2. Clean Lead Facility Main Switchboard Screen

The inventory system includes standard reports. These may be printed directly by selecting the Reports button on the Main screen and pressing one of the buttons on the pop-up Reports screen shown in Figure 3. Sample copies of these reports are included in Appendix B. If additional reports are required for ad hoc queries and/or special reports, refer to Appendix D to perform queries on data with attached databases. 
INEL-94/0237

Rev. 0

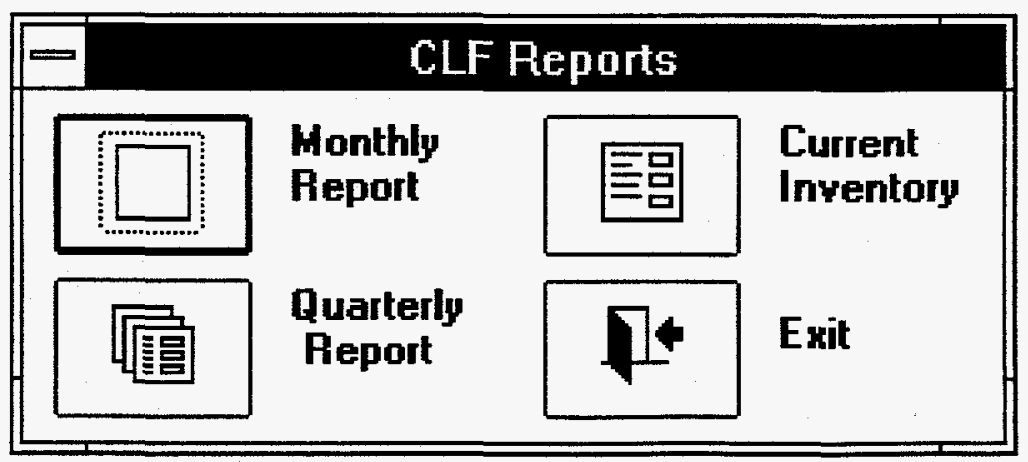

Figure 3. Clean Lead Facility Reports Screen

\subsection{DATA ENTRY PROCEDURES}

When changes to the inventory occur, they must be entered into the inventory system. Data is input by personnel from Waste Reductions Operation Complex (WROC) using the shipping papers and/or related documentation for the subject lead items. The inventory system contains information on each incoming shipment of lead and each outgoing shipment of lead from the facility. The system has been designed to make data entry easy and to produce standard reports from the entered information. It is important to make sure all data is promptly entered, verified, and complete to ensure correct reports.

The inventory system is comprised of three data entry screens: the receiving log screen, the shipping log screen, and the new lead items screen. The inventory screens contain identification and quantification data for each lead shipment. The lead types screen identifies the types of lead that may be stored or shipped.

The system was designed for data entry of lead shipments. To ensure the integrity of the data is maintained, it should be entered into the system at the time the transaction is made. With the system maintained by prompt data entry, the user can view the current inventory at leisure and be confident the system will provide accurate information. To ensure the system reflects the actual current storage, the facility manager should implement routine inventory walkdowns. Any discrepancies should be immediately resolved by reviewing the past records.

\subsection{Entering New Shipments of Lead into Inventory}

In order to enter new information about outgoing shipments of lead into the inventory system, a new record must be created. The following steps explain how a new record is created. 
INEL-94/0237

Rev. 0

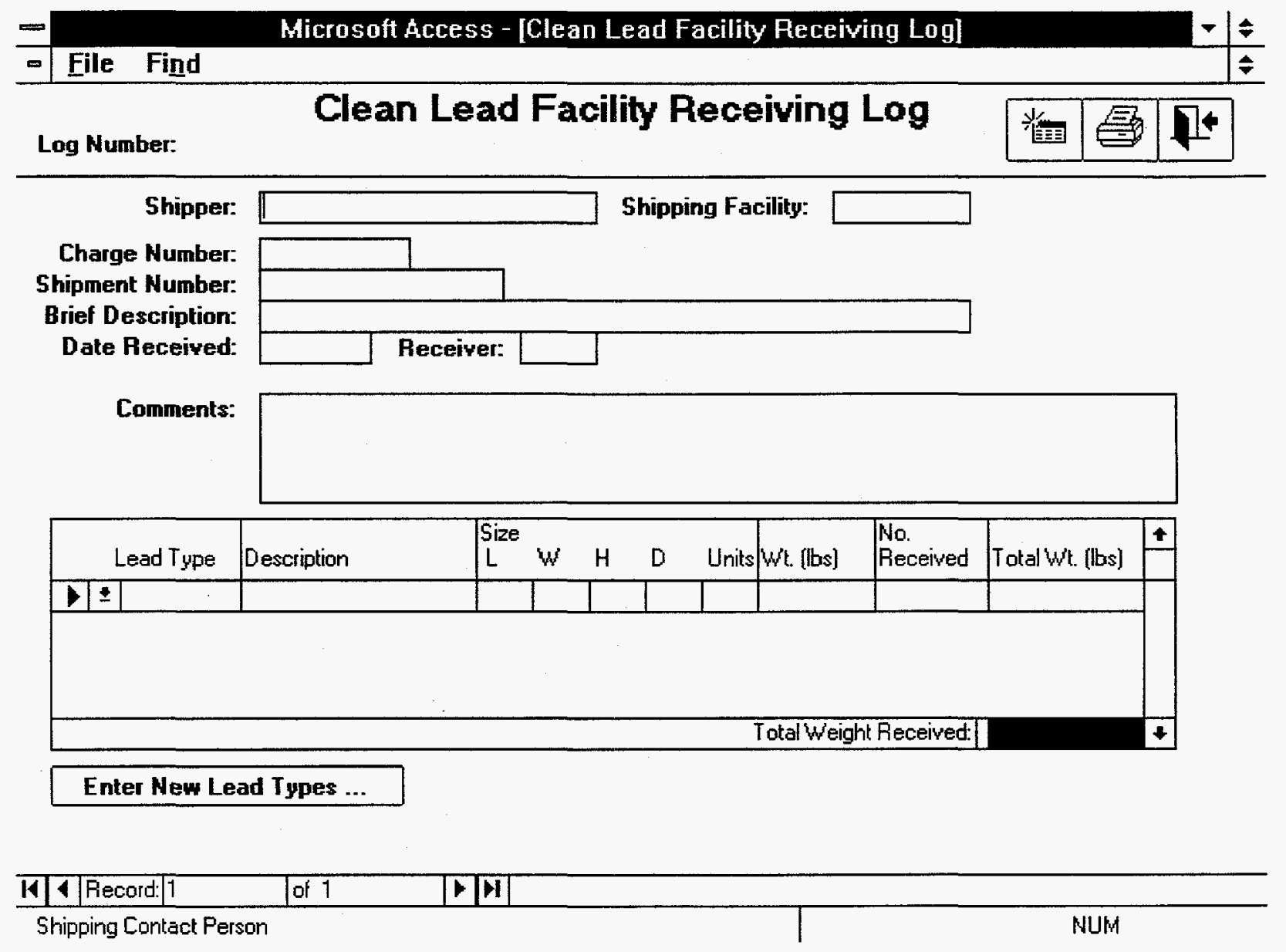

Figure 4. Clean Lead Facility Receiving Log Screen

1. From the inventory screen (refer to Figure 4), new records can be created through three means. The new record button located in the header can be pushed, or pull down the FIND menu and select GO TO NEW or move to the last record by pressing the last record navigation button then press the next record navigation button. The file navigation buttons are located at the bottom left corner of the screen.

2. Using the information on the shipping papers, enter the data as completely as possible. The lower portion of the screen contains a section for the lead details. The status bar at the bottom of the screen contains a brief description of the data that should be entered into each field. Upon entering each field, the text in the status bar will change for the particular field.

3. The shipment number is required before moving to another screen. The lead items can be picked from the pull down box located in the lower section of the form for each lead line 
item. The count of each item received can also be entered.

4. After completion of the data entry, the record should be printed by pressing the print button located in the header section of the screen or selecting PRINT from the FILE menu. The data can be verified and checked with the incoming shipment using the printout. This profile report should be filed with any other pertinent documentation regarding the shipment.

\subsection{Entering New Shipments of Lead Leaving the Facility}

In order to enter new information about outgoing shipments of lead into the inventory system, a new record must be created. The Shipping Log screen is similar in design and function as the Receiving Log screen. The following steps explain how a new record is created.

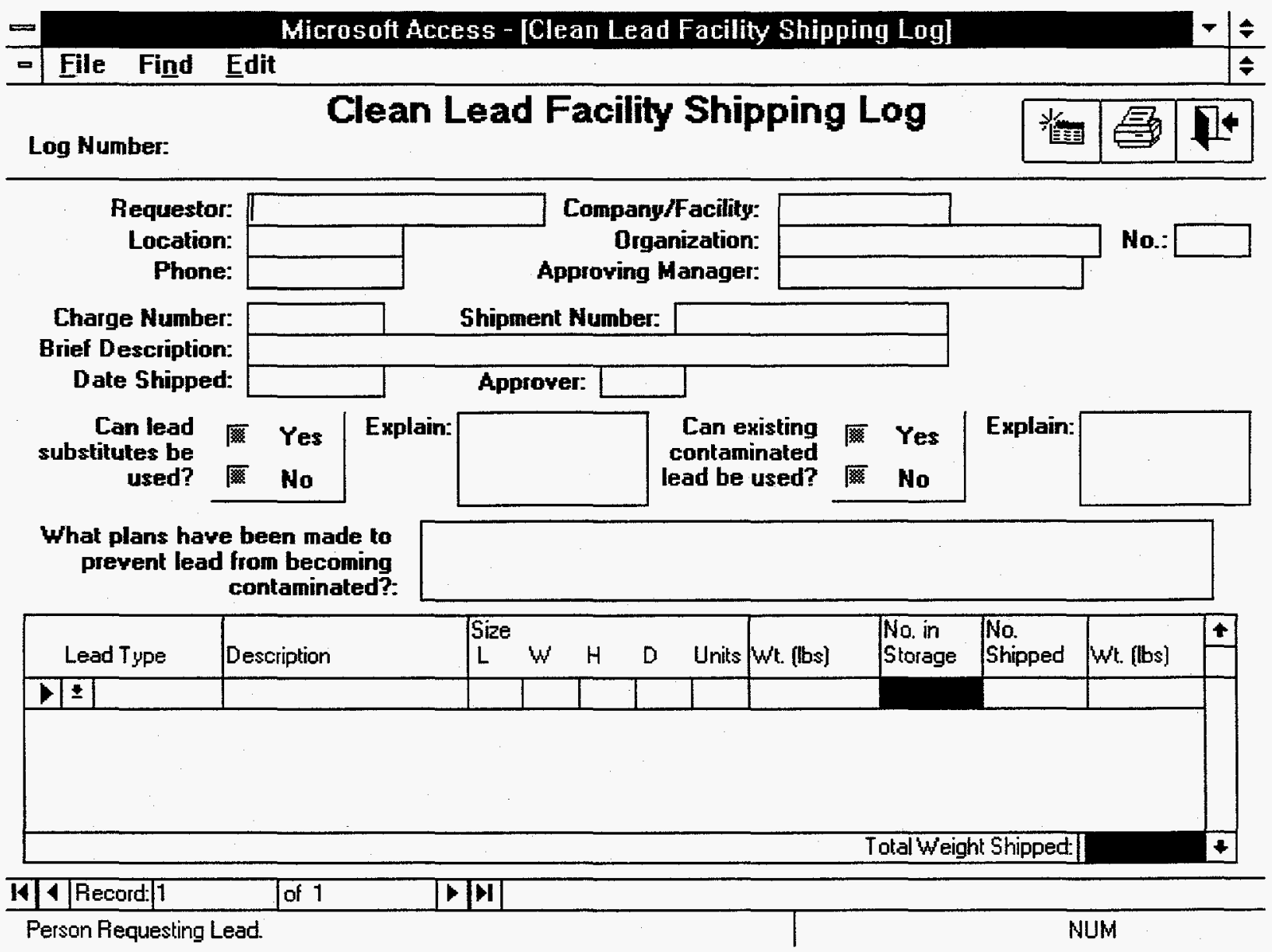

Figure 5. Clean Lead Facility Shipping Log Screen 
1. From the inventory screen (refer to Figure 5), new records can be created through three means. The new record button located in the header can be pushed, or pull down the FIND menu and select GO TO NEW or move to the last record by pressing the last record navigation button then press the next record navigation button. The file navigation buttons are located at the bottom left corner of the screen.

2. Using the information on the shipping papers and form EG\&G-0184, LEAD USAGE/PURCHASE JUSTIFICATION, enter the data as completely as possible. The lower portion of the screen contains a section for the lead details. The status bar at the bottom of the screen contains a brief description of the data that should be entered into each field. Upon entering each field, the text in the status bar will change for the particular field.

3. The shipment number is required before moving to another screen. The lead items can be picked from the pull down box located in the lower section of the form for each lead line item. The number of each item to ship can also be entered. The pull down box only shows those items which are currently in storage. The number of items in storage for the lead type picked is a calculation based on all incoming and all outgoing lead shipments. If discrepancies are found, refer to Section 9.1, Troubleshooting and Resolving Inventory Discrepancies, for more information.

4. After completion of the data entry, the record should be printed by pressing the print button located in the header section of the screen. The data can be verified and checked with the outcoming shipment using the printout. This profile report should be filed with any other pertinent documentation regarding the shipment.

\subsection{Entering New Lead Types}

The structure of this database system should not be confused with other database systems that uniquely identify each container. Since it would not be feasible to identify each lead item in the CLF, the lead type concept was initiated. In other words, the system inventories the lead based on its unique lead type identification and the actual count of the items. The development of the CLF database with this concept produced a unique database structure that sets relationships between all lead shipments and the lead types. This system can be compared to a grocery store inventory system. For example, a grocer is concerned about the quantity of items exchanged and not necessarily on which item was exchanged.

The lead types in this inventory system are used to uniquely identify each type of lead item in storage. The uniqueness of the lead type for the CLF inventory system is a key element to the usefulness and success of the entire system. The facility manager should consider options to uniquely identify each lead type. With the lead type being the keystone of the database structure, the ability to modify the lead types table was minimized to allow data entry and view privileges only. Once the lead type is entered into the system, it cannot be edited. The importance of good data and lead identification options needs to be well planned for future shipments. The management of the lead in storage also plays a major role in 
ensuring the data integrity is maintained. Appendix $C$ explains the process and gives guidance on uniquely identifying lead types.

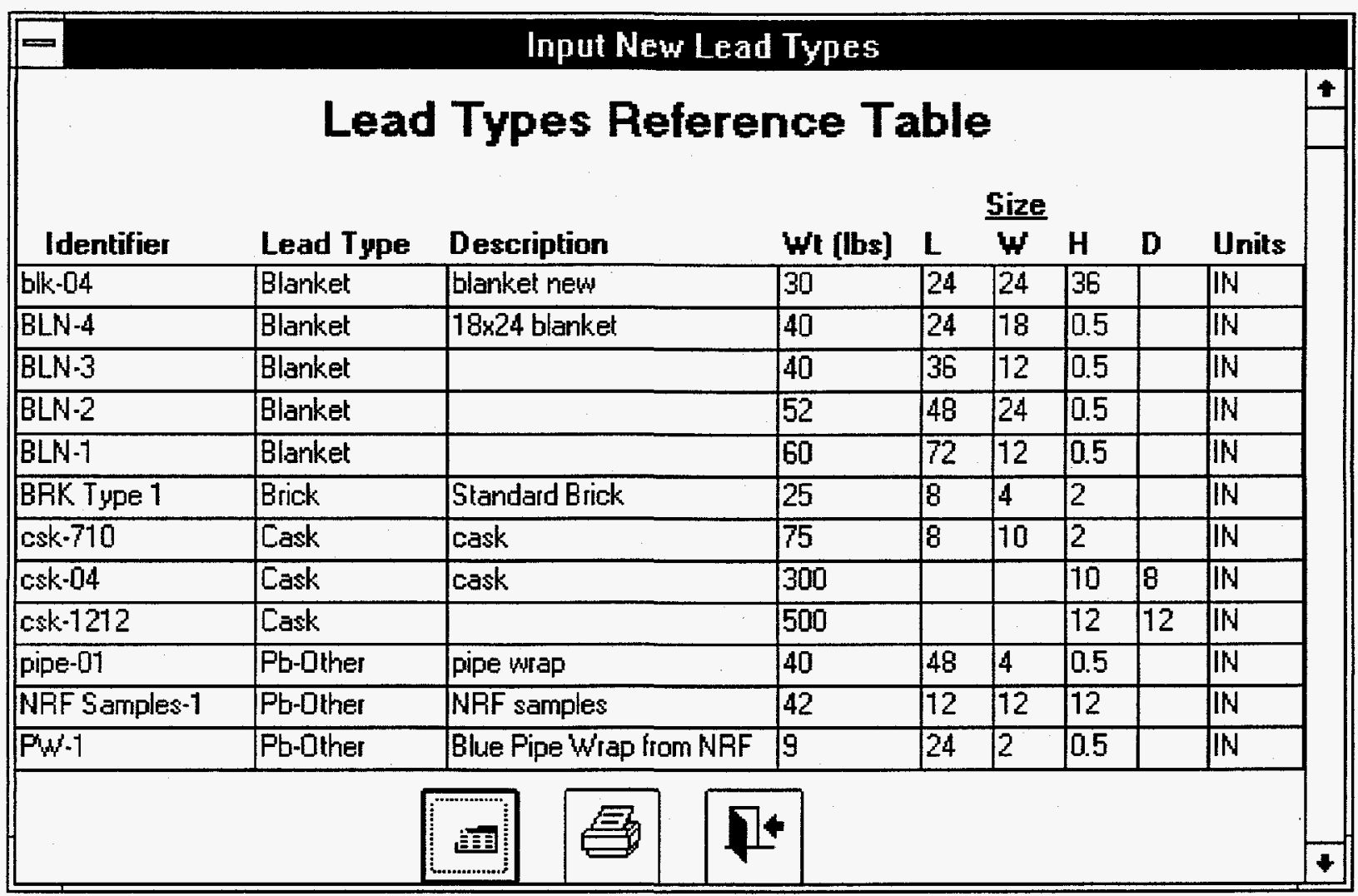

Figure 6. Clean Lead Facility Lead Types Reference Table Screen

The Lead Types Reference Table (refer to Figure 6) is an on-screen report that can be viewed by pressing the Lead Types button from the Main Switchboard screen. A hardcopy table can be obtained by pressing the Print button on the screen. The Reference Table is the table the database system uses to identify the relationships with the other database tables. Each item on this table is identified and entered by the user. 


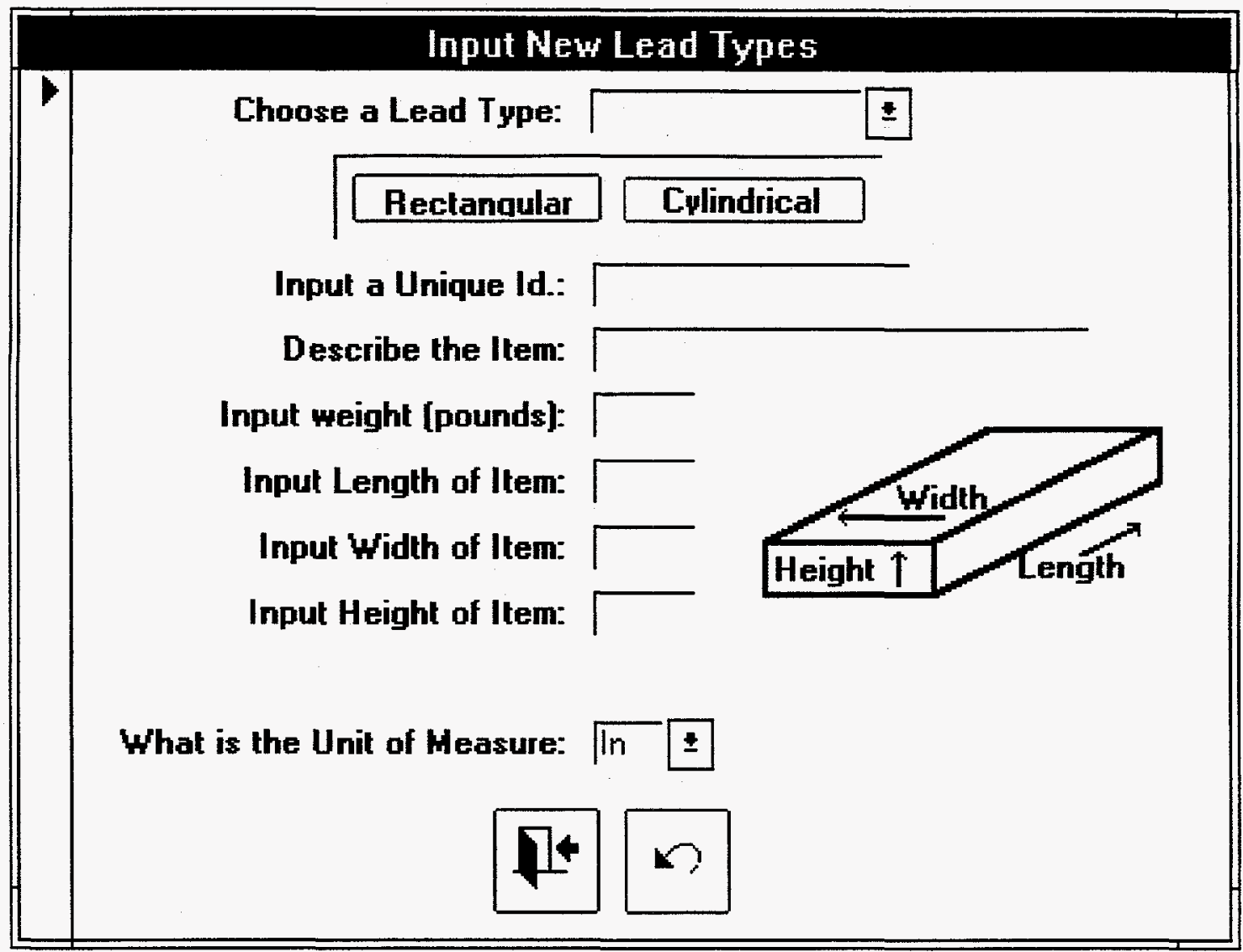

Figure 7. Clean Lead Facility Lead Types Entry Form Screen

1. Entry of new lead types can be accomplished in two areas, by pressing the new lead types button from the Lead Types Reference Table, Figure 6, or from the Receiving Log screen (refer to Figure 4). Either button will display the same data entry form, Figure 7, and allow the same data entry capabilities.

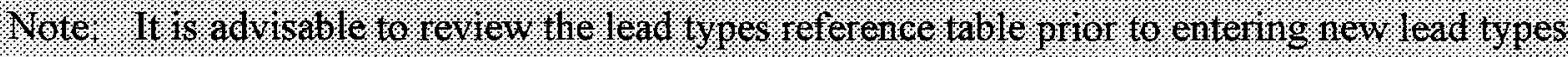
to ensure that hie lead in girestion has nol alleady been entered

2. Select the most suitable lead form from the pick list. Select the most suitable object shape with the object shape option button. This field is used to determine the necessary volume formula to use in volume calculations and allows the user to enter the appropriate fields for doing volume calculations. The dimensions should be entered according to the drawing that is displayed for each lead shape. 
3. Enter the unique id number for the lead type. This identifier will be used for referencing the lead type in the Receiving and Shipping screens.

4. Enter the weight in pounds, the dimensions, and the units in the appropriate fields. Depending on the object shape picked (Rectangular or Cylindrical) the Length, Width, Height, and/or Diameter fields are available.

5. All visible fields are required to be completed. If the fields are not completed then the record cannot be saved. Pressing the undo button will remove the values from the screen, allowing the user to exit the form without saving the record. It is important to have all lead parameters available at the time of entering the data since once the record is added, it cannot be changed.

6. Exit the form by pressing the exit button. The lead type can then be picked from the pick list for data entry purposes or viewed and printed from the Lead Types Reference Table.

\subsection{REPORTS}

Standard reports are included with the inventory system. The shipment profile's report buttons are located on the respective screens and the summary reports buttons are located in the Reports screen. The Reports screen can be viewed by pressing the reports button on the Main Switchboard screen. If additional ad hoc reports are needed, see Appendix D for instructions on attaching databases and generating queries and reports.

The reports include a record profile for both shipping and receiving lead shipments. Upon completion of the data entry, the profile report can be printed by pressing the print button. Past records can also be printed in the same manner. The lead reference table which includes all records of lead types entered into the system can be printed by pressing the lead types button on the Main Switchboard to view the on screen report and pressing the print button for a hard copy.

The summary reports, Current, Monthly, Quarterly can be printed by pressing the reports button on the Main Switchboard and selecting the appropriate button on the popup form. This form can be closed by pressing the exit button.

The Quarterly Report will prompt the user to input a year for the report before the report is generated. The quarterly report includes volume and weight summaries by lead type for each quarter in the year. A annual summary is also included on the Quarterly Report. This report is typically three pages long.

The Monthly Report will prompt the user to input a year and month prior to the report being generated. A summary of the lead type shipped or received will be printed that includes a count and weight of each lead type. This report is typically two pages long depending on the number of shipments and number of lead types received for the particular month. 


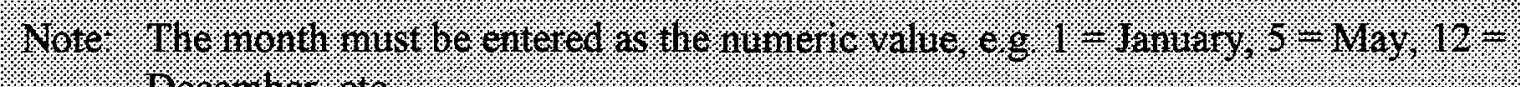
Decentier. et:

The Current inventory report will produce a report of all lead in current inventory based on the current date the report was generated. This report is useful for inventory walkdowns and up-to-date inventory reporting. The count, weight, and total weight of all lead will be produced. This report is typically one page long depending on the number of lead types in storage.

\subsection{SECURITY}

MS Access has security features to prevent unauthorized users from using and/or changing information in the database. The password and user id information is stored in a workgroup file associated with the use of the database system. Each user will be supplied with a user id or name and default password.

\subsection{Joining A Workgroup}

The workgroup associated with the CLF Inventory System is located on the PBF601 server with a complete path of U:IDATABASEIIMWI.MDA. To perform work on the Inventory System, the PC station you are using must be connected to the workgroup. Upon entering the MS Access program, you should be prompted for a name and a password. If this does not happen, then the PC station needs to be joined to the appropriate workgroup. Be aware that other workgroups may be on the server and may also prompt the user for access information. This procedure assumes that the PC station is connected to the server. If additional assistance is needed, refer to Section 9.0, Technical Support. To join the workgroup for the CLF Inventory System, proceed as follows:

1. Exit MS Access as normal.

2. Open the MS Access program group. Open the MS Access Workgroup Administrator icon. A sequence of dialog boxes will follow depending on which buttons are pressed.

3. If the System Database does not specify the complete path mentioned, then go to step 4. If problems are encountered then refer to Section 9.0, Technical Support.

4. Press the Join button, then the Browse button to search for the appropriate workgroup.

5. When the workgroup is located and highlighted, press the OK and EXIT buttons on the various screens till the Workgroup Administrator program is closed. An information dialog box should display the workgroup you joined.

6. Proceed with the normal log-on feature, See Section 4.0, Accessing the Inventory System. 
INEL-94/0237

Rev. 0

\subsection{Changing the Password}

To change the password:

1. Select SECURITY from the menu bar on the Main Switchboard screen.

2. Select NEW PASSWORD, type the new password and verify its entry.

Note: The passwords are case sersitive:

It is recommended that at least 2 individuals have a valid user id and password to maintain access to the data in case of illness or personal leave. Each person who needs access to the information should have a unique password and user id.

\subsection{ARCHIVING DATA}

It is important to keep archived copies of the inventory data to use in the case of computer failure or data corruption. A copy of the inventory database should be made weekly and added to the archive, unless no changes to the data have been made during the week. Where lead is received and/or shipped infrequently, it is recommended that a back up be made on the day when data changes are made.

\section{GAUTION:}

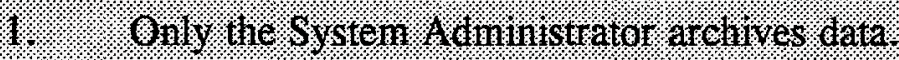

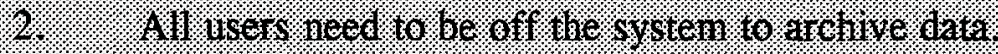

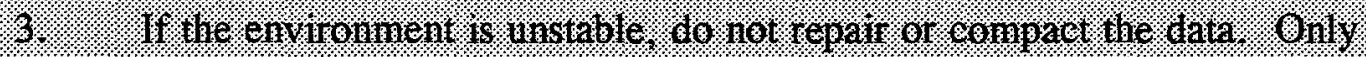

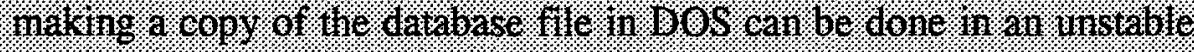

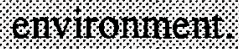

To make a back up copy of the inventory data:

1. Exit the Inventory System main screen by clicking on the QUIT button.

2. From the MS Access menu bar select FILE and REPAIR DATABASE. A Repair

Database dialog box will appear. 
3. Select the inventory system data file with the appropriate path U:IDATABASE\CLF\CLF.MDB and click on OK with the mouse.

4. The system will indicate when the repair has been completed successfully.

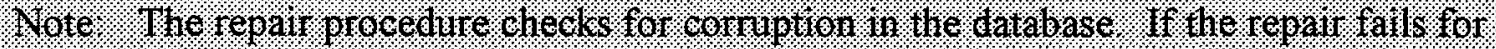

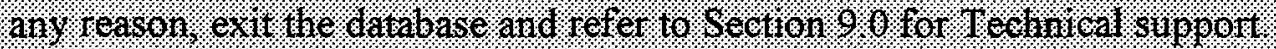

5. From the MS Access menu bar select FILE and COMPACT DATABASE. A Compact Database dialog box will appear.

6. Select the inventory system data file with the appropriate path to compact from and click OK with the mouse.

7. Select the same inventory system data file, with the appropriate path, to compact into and click on OK with the mouse. The system will indicate that this file exists. Select OK to overwrite the file.

Note. The compret procedire ninmizes the anrount of disk space required for the archived Miles and tedices file frasmentation. If the compact operation fats for

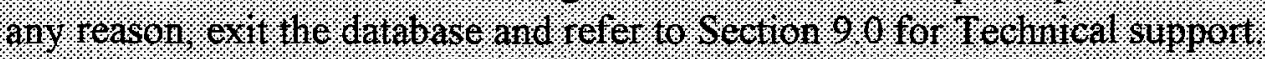

8. After the data has been compacted, from the MS Access menu bar select FILE and EXIT.

9. Exit the MS Windows program manager and return to a DOS prompt. Alternately, in a stable environment, the File Manager in MS Windows can be used to copy the file.

10. Format a new diskette for the backup and label it: Clean Lead Facility Inventory System Backup \#X (Where $\mathrm{X}$ is the consecutive number of the next backup disk.) and list the date of the backup.

11. Check the file size on both the diskette and the hard disk to make sure they are the same using the 'DIR' DOS command.

12. Copy the file from the hard disk to the diskette using standard DOS commands. (e.g., copy U:IDATABASE \CLF\CLF.MDB a:CLF.mdb /v) Note the /v parameter will verify the copy process. 


\section{IMPORTAIT NOTE:}

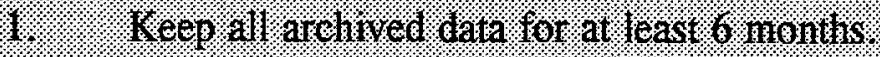

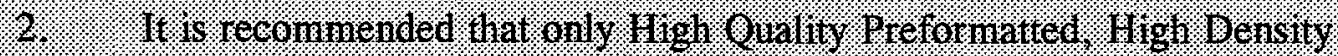

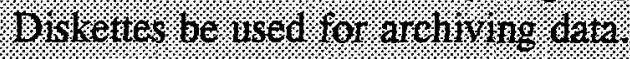

\subsection{TECHNICAL SUPPORT}

In case of problems with the use or operation of this Inventory System, contact Shawn Parkinson, 526-8054, or one of the following personnel:

Craig Bates, Network and MS Access Support, OVID: BAT Phone: 526-8564

Juan Garcia, CLF Inventory System and MS Access Support, OVID: JUA Phone: 526-6649

Justin Tozer, Database Adminstrator and MS Access Support, OVID: JUZ Phone: 526-9250

In case of problems with Microsoft Windows or Microsoft Access, contact Microsoft Product Support Services at (206) 635-7050.

\subsection{Troubleshooting and Resolving Inventory Discrepancies}

Most problems encountered in inventory systems are the result of poor data quality. All fields should be filled-in as completely and accurately as possible. Some fields require data entry and will not allow a record to be saved if it is not completed. Missing or erroneous dates, missing or misspelled fields, and improperly identified and counted lead items can result in inaccurate reports and inventory system. After a record is completed for a shipment, it should be printed and reviewed for accuracy by another person familiar with the CLF. Space is available on the printouts to verify the data was reviewed and accepted. The inventory system should be maintained by someone who is familiar with the types of lead in storage and the types of lead identified on the inventory system. Training on using the inventory system may also eliminate some data quality errors.

Since the CLF database is closely related to the lead-types, the complete and efficient identification of the lead-types is stressed. After a usable identification scheme is established, it needs to be closely followed and maintained. The reference table should be reviewed before entering any new lead-types.

The shipping log screen allows the user to pick only those lead items received, entered in the inventory system, and currently in storage. If a lead-type is being shipped out and it is not identified on the inventory system then the records need to be reviewed to decide if the lead-type was missed, improperly labeled, or improperly received. 
The routine inventory walkdowns should both reflect the current inventory and the database inventory at any time. Discrepancies should be immediately resolved by reviewing records and data entries. The discrepancies should be documented. If consistent inventory discrepancies are discovered, then additional controls on the inventory systems may need to be set up. The technical advisors mentioned in Section 9.0 can probably explain some options for setting up stricter controls for the Inventory System.

\subsection{REFERENCES}

1. DOE/ID-10381, Rev. 1, Idaho National Engineering Laboratory Reusable Property, Recyclable Materials, and Waste Acceptance Criteria, February 1994.

2. Microsoft Access 2.0 User's Guide, 1994. 


\begin{tabular}{|c|c|c|c|c|}
\hline $\begin{array}{l}\text { Field } \\
\text { Name }\end{array}$ & $\begin{array}{l}\text { Field } \\
\text { Description }\end{array}$ & $\begin{array}{l}\text { Fieid } \\
\text { Type }\end{array}$ & $\begin{array}{l}\text { Field } \\
\text { Size }\end{array}$ & Indexed? \\
\hline \multicolumn{5}{|c|}{ Table:LEAD_IN_ITEMS } \\
\hline LEAD_U_ID & $\begin{array}{l}\text { Lead Type Unique Idenification Number (from Table } \\
\text { LEAD_TYPES_LOOKUP) }\end{array}$ & Number (Long) & 4 & Yes \\
\hline ITEM_COUNT & Number of Items. & Number (Long) & 4 & No \\
\hline U_ID_IN & Unique Record Number & Text & 15 & Yes \\
\hline \multicolumn{5}{|c|}{ Table:LEAD_IN_MASTER } \\
\hline COMMENTS & Parameter Information Sources & Memo & - & No \\
\hline RECEIVED_BY & $\begin{array}{l}\text { Initials of Authorized Person Receiving Material at } \\
\text { the CLF. }\end{array}$ & Text & 3 & No \\
\hline CHARGE_NUM & Charge Number Used to Accept Material & Text & 9 & No \\
\hline GEN_FACIL & Shipping Facility (e.g., TAN545, TRA613, etc.) & Text & 8 & No \\
\hline GENNAME & Shipping Contact Person & Text & 30 & No \\
\hline MANIFESTIN & In Coming Shipment Number & Text & 20 & Yes \\
\hline WASTE & Brief Description of Shipment. & Text & 75 & No \\
\hline DATERCVD & Date the Shipment of Lead was Received. & Date/Time & 8 & No \\
\hline U_ID_IN & Unique Log Number for Lead Received. & Text & 12 & Yes \\
\hline SYS_NUM & $\begin{array}{l}\text { Counter Field Used to Generate Log Number on } \\
\text { Forms. }\end{array}$ & Number (Long) & 4 & No \\
\hline
\end{tabular}

Table:LEAD_OUT_ITEMS

$\begin{array}{lllll}\text { LEAD_U_ID } & \text { Lead Type Unique Idenification Number (from Table } & \text { Number (Long) } & 4 & \text { Yes } \\ & \text { LEAD_TYPES_LOOKUP) } & \text { Number (Long) } & 4 & \text { No } \\ \text { ITEM_COUNT } & \text { Number of Items. } & \text { Text } & 20 & \text { No }\end{array}$

Table:LEAD_OUT_MASTER

$\begin{array}{lllll}\text { RECEIVER_PHO } & \text { Phone Number of Requestor. } & \text { Text } & 13 & \text { No } \\ \text { RECEIVER_LOC } & \text { Requestor's Location. } & \text { Text } & 10 & \text { No } \\ \text { SYS_NUM } & \text { Counter Field Used to Generate U_ID. } & \text { Number (Long) } & 4 & \text { No } \\ \text { U_ID_OUT } & \text { Unique Id Field Used as the CLF Log Number. } & \text { Text } & 20 & \text { Yes } \\ \text { DATEOUT } & \text { Date the Lead was Shipped. } & \text { Date/Time } & 8 & \text { No } \\ \text { WASTE } & \text { Brief Description of Shipment. } & \text { Text } & 75 & \text { No } \\ \text { MANIFESTOUT } & \text { Out Going Shipment Number. } & \text { Text } & 20 & \text { Yes }\end{array}$




\begin{tabular}{|c|c|c|c|c|}
\hline $\begin{array}{l}\text { Field } \\
\text { Name }\end{array}$ & $\begin{array}{l}\text { Field } \\
\text { Description }\end{array}$ & $\begin{array}{l}\text { Field } \\
\text { Type }\end{array}$ & $\begin{array}{l}\text { Field } \\
\text { Size }\end{array}$ & Indexed? \\
\hline COMMENTS & Parameter Information Sources & Memo & $\overline{-}$ & No \\
\hline RECEIVER & Person Requesting Lead. & Text & 30 & No \\
\hline SHIPPED_BY & $\begin{array}{l}\text { Initials of Person Authorizing Shipment of Material } \\
\text { from the CLF. (Usually the Facility Manager). }\end{array}$ & Text & 3 & No \\
\hline RECEIVER_DAT & Date the Requestor Placed Form EG\&G-0184. & Date/Time & 8 & No \\
\hline CHARGE_NUM & Charge Number Used to Ship Material & Text & 9 & No \\
\hline MANAGER_DAT & Date the Group Manager Approved Lead Usage. & Date/Time & 8 & No \\
\hline MANAGER & Approving Group Manager Name. & Text & 30 & No \\
\hline LEAD_CONT_EX & $\begin{array}{l}\text { If No, Explain Why Contaminated Lead Cannot be } \\
\text { Used. }\end{array}$ & Text & 100 & No \\
\hline LEAD_EXPLAIN & $\begin{array}{l}\text { If No, Explain Why a Lead Substitute Cannot be } \\
\text { Used. }\end{array}$ & Text & 100 & No \\
\hline LEAD_SUB & Can Lead Substitutes be Used? $(1=$ Yes, $2=$ No) & Number (Byte) & 1 & No \\
\hline ORG_NUM & Requestor's Organization Number. & Text & 5 & No \\
\hline ORG & Requestor's Organization Name. & Text & 30 & No \\
\hline REC_FACIL & $\begin{array}{l}\text { Requesting Facility or Company(e.g., RWMC, } \\
\text { TRA613, etc.). }\end{array}$ & Text & 15 & No \\
\hline LEAD_CONT_SU & $\begin{array}{l}\text { Can Existing Contaminated Lead be Used? }(1=\text { Yes, } \\
2=\text { No) }\end{array}$ & Number (Byte) & 1 & No \\
\hline
\end{tabular}

Table:LEAD_TYPES_LOOKUP

\begin{tabular}{|c|c|c|c|c|}
\hline NOMINAL_LBS & Nominal Weight of Lead Type in Pounds. & Number (Double) & 8 & No \\
\hline ITEM_DIAMETE & Diameter of ltem. & Number (Double) & 8 & No \\
\hline ITEM_HEIGHT & Height of Item. & Number (Double) & 8 & No \\
\hline ITEM_WDTH & Width of Item. & Number (Double) & 8 & No \\
\hline ITEM_LENGTH & Length of Item. & Number (Double) & 8 & No \\
\hline ITEM_SIZE_UNIT & Physical Dimension Units. In = inches, $M=$ Meters & Text & 2 & No \\
\hline LEAD_U_ID & Unique Lead Identification Number. & Number (Long) & 4 & Yes \\
\hline LEAD_TYPE & Type of Lead Item (Brick, Blanket, etc.) & Text & 15 & No \\
\hline LEAD_IDENTIFIE & Unique Identifier Defined by the User. & Text & 15 & Yes \\
\hline VOLUME_CALC & $\begin{array}{l}\text { Volume Calculation Identifier }(1=\text { Rectangular, } L \times \\
\left.W \times H ; \text { and } 2=\text { Cylindrical, pi } \times D^{\wedge} 2 / 4 \times H\right)\end{array}$ & Number (Byte) & 1 & No \\
\hline LEAD_DESC & $\begin{array}{l}\text { Physical Description of Item. Include Names, Color, } \\
\text { Use, etc. }\end{array}$ & Text & 40 & No \\
\hline
\end{tabular}


INEL-94/0237

Rev. 0

\section{APPENDIX B: SAMPLE REPORTS}

B-1 


\section{Clean Lead Facility Receiving Log}

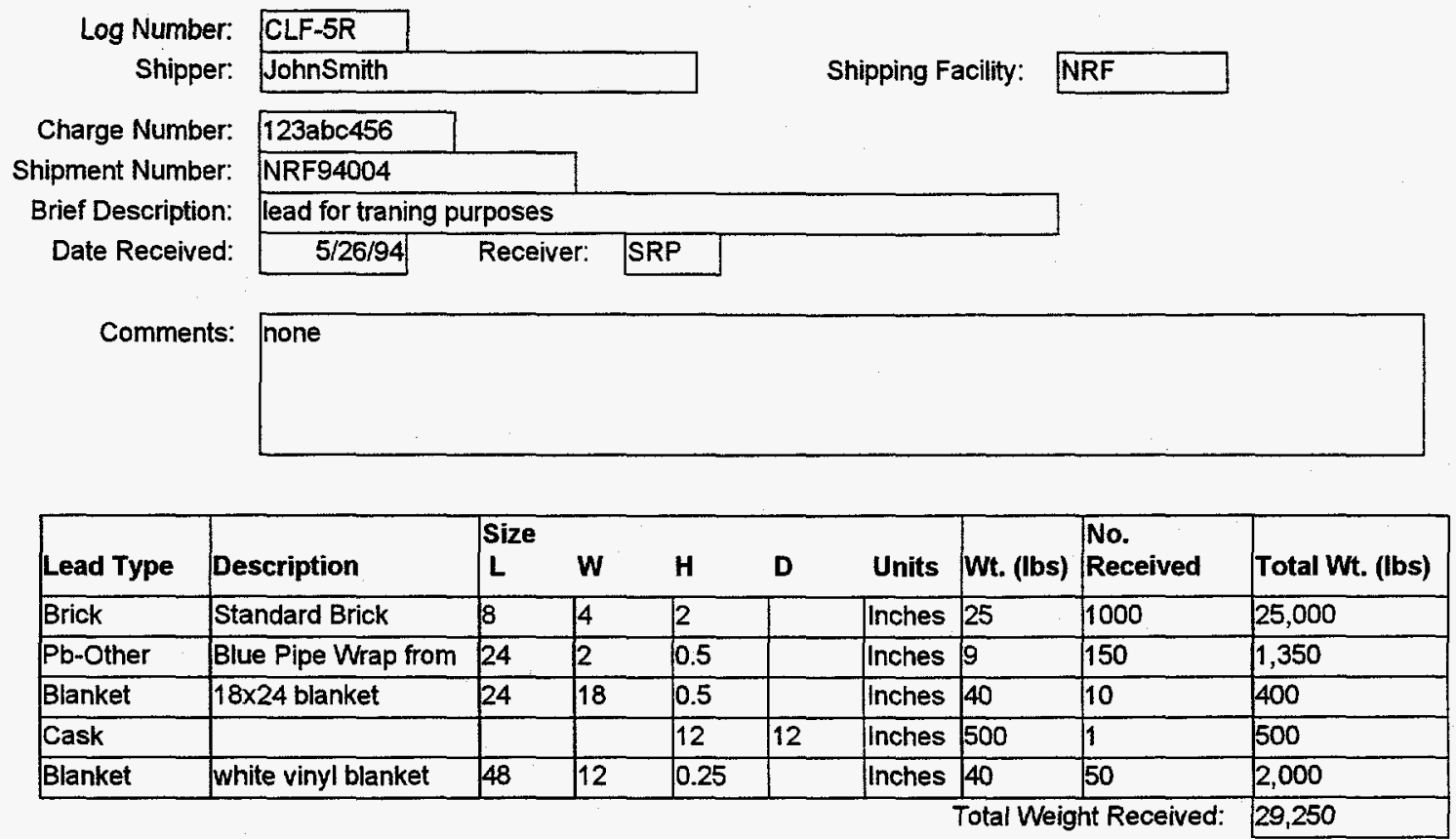

Data Entry Verified By:

Receiving Record Verified By: 


\section{Clean Lead Facility Shipping Log}

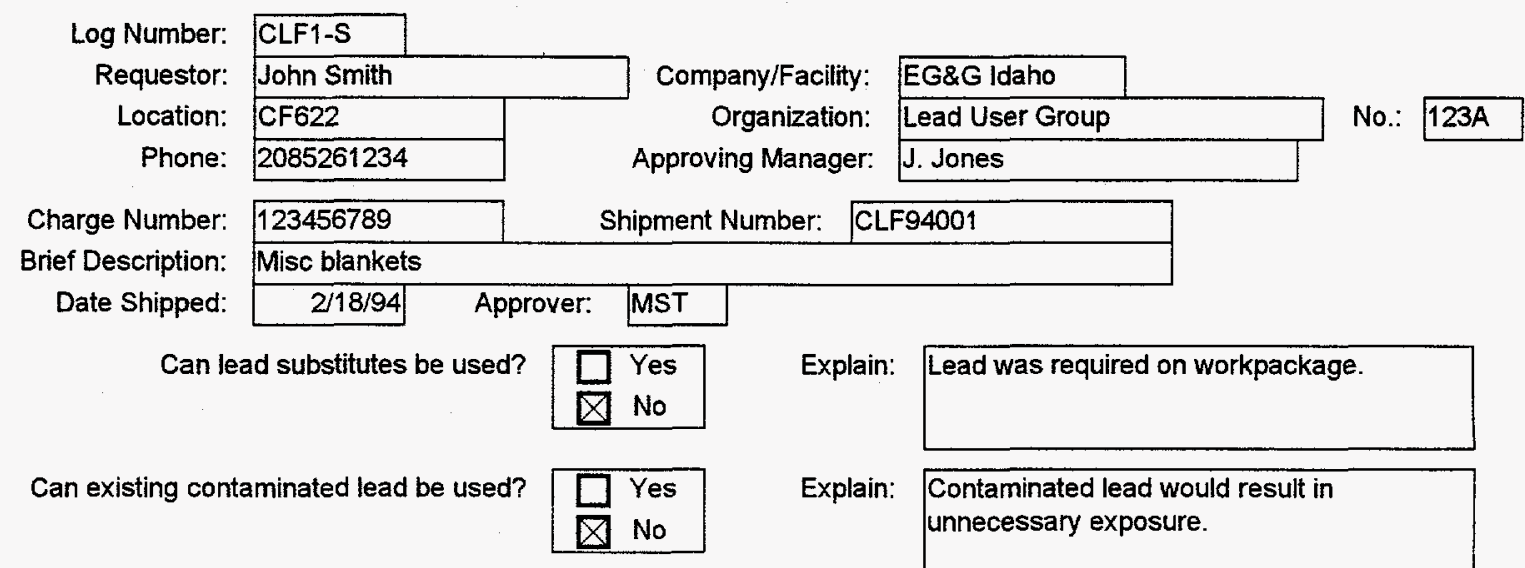

What plans have been made to prevent lead Blankets will not be used in a contaminated area. from becoming contaminated?

\begin{tabular}{|l|l|l|l|l|l|l|l|l|l|}
\hline Lead Type & Description & $\begin{array}{l}\text { Size } \\
\text { L }\end{array}$ & W & H & D & Units & Wt. (Ibs) & $\begin{array}{l}\text { No. } \\
\text { Shipped }\end{array}$ & Total Wt. (Ibs) \\
\hline Blanket & & 36 & 12 & 0.5 & & Inches & 40 & 3 & 120 \\
\hline Blanket & $18 \times 24$ blanket & 24 & 18 & 0.5 & & Inches & 40 & 52 & 2,080 \\
\hline Blanket & White vinyl blanket & 48 & 12 & 0.25 & & Inches & 40 & 1 & 40 \\
\hline
\end{tabular}

Data Entry Verified By: Shipment Record Verified By: 
CLF Lead Types Reference Table

\begin{tabular}{|c|c|c|c|c|c|c|c|c|}
\hline Unique Id. & Lead Type & Description & Nominal Wt. (lbs) & Length & Width & Height & Diameter & Size Units \\
\hline BLN-1 & Blanket & & 60 & 72 & 12 & 0.5 & & Inches \\
\hline BLN-2 & Blanket & & 52 & 48 & 24 & 0.5 & & Inches \\
\hline BLN-4812 & Blanket & white vinyl blanket & 40 & 48 & 12 & 0.25 & & Inches \\
\hline BLN-3 & Blanket & & 40 & 36 & 12 & 0.5 & & Inches \\
\hline blk-04 & Blanket & blanket new & 30 & 24 & 24 & 36 & & Inches \\
\hline BLN-4 & Blanket & $18 \times 24$ blanket & 40 & 24 & 18 & 0.5 & & Inches \\
\hline BRK Type 1 & Brick & Standard Brick & 25 & 8 & 4 & 2 & · & Inches \\
\hline csk-1212 & Cask & & 500 & & & 12 & 12 & Inches \\
\hline csk-710 & Cask & cask & 75 & 8 & 10 & 2 & & Inches \\
\hline csk-04 & Cask & cask & 300 & & & 10 & 8 & Inches \\
\hline PW-1 & $\mathrm{Pb}$-Other & Blue Pipe Wrap from NRF & 9 & 24 & 2 & 0.5 & & Inches \\
\hline NRF Samples-1 & $\mathrm{Pb}$-Other & NRF samples & 42 & 12 & 12 & 12 & & Inches \\
\hline pipe-01 & $\mathrm{Pb}$-Other & pipe wrap & 40 & 48 & 4 & 0.5 & & Inches \\
\hline other lead & $\mathrm{Pb}$-Other & & 1 & 1 & 1 & 1. & & Inches \\
\hline pipe-02 & $\mathrm{Pb}$-Other & hollow lead pipe & 450 & & & 57 & 7 & Inches \\
\hline scrp-001 & Scrap & scrap & 50 & & & 8 & 2 & Inches \\
\hline
\end{tabular}




\section{CLF Monthly Summary Report for May 1994}

\section{Lead Received}

No Lead Received this Month 


\section{CLF Monthly Summary Report for May 1994}

\section{Lead Shipped}

\section{Log No. Date Shipped Shipping Summary}

CLF3-S 11-May-94 Manifest No: CLF94003, blankets, Receiver: B. Jones, Facility: EG\&G Idaho, CLF Shipper: SRP

\begin{tabular}{|c|c|c|c|c|}
\hline Lead Details: & Unique ld. & Type & Description & No. of Items \\
\hline & $B L N-4$ & Blanket & $18 \times 24$ blanket & 89 \\
\hline CLF5-S & 19-May-94 & $\begin{array}{l}\text { Manifest N } \\
\text { Shipper: LI }\end{array}$ & 5, blankets, Re & TCO, CLF \\
\hline Lead Details: & Unique Id. & Type & Description & No. of ltems \\
\hline & $\overline{B L N-3}$ & Blanket & & 47 \\
\hline & BLN-4 & Blanket & $18 \times 24$ blanket & 18 \\
\hline
\end{tabular}




\section{Current Lead Inventory for Wednesday, January 25, 1995}

\begin{tabular}{|c|c|c|c|c|c|c|c|c|c|}
\hline Unique Id. & Lead Type & Description & Length & Width & Height & Diameter & Size Units & No. in Storage & I Wt. (Ibs) \\
\hline BLN-4812 & Blanket & white vinyl blanket & 48 & 12 & 0.25 & & Inches & 849. & (6) \\
\hline BLN-4 & Blanket & $18 \times 24$ blanket & 24 & 18 & 0.5 & & Inches & 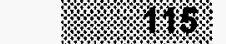 & 89600 \\
\hline BLN-3 & Blanket & & 36 & 12 & 0.5 & & Inches & 3\%\% & 19.9621 \\
\hline BLN-2 & Blanket & & 48 & 24 & 0.5 & & Inches & 6712. & 8600 \\
\hline BRK Type 1 & Brick & Standard Brick & 8 & 4 & 2 & & Inches & 18,962 & $344 \% 325$ \\
\hline csk-1212 & Cask & & & & 12 & 12 & Inches & W/י & 600 \\
\hline pipe-02 & $\mathrm{Pb}$-Other & hollow lead pipe & & & 57 & 7 & Inches & (1) & 146 \\
\hline$P W-1$ & $\mathrm{~Pb}$-Other & Blue Pipe Wrap from NRF & 24 & 2 & 0.5 & & Inches & \% $\%$ \% & 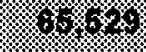 \\
\hline Shot \#7 & Shot & Lead Shot in Boxes & 6 & 4 & 4 & & Inches & $11 \%$ & 284 \\
\hline
\end{tabular}




\section{CLF Quarterly/Annual Report for 1994}

\section{Quarter-1}

Lead Items Received:

\begin{tabular}{|c|c|c|c|c|}
\hline Type & Description & Count & Volume (ft3) & Weight (lbs) \\
\hline Brick & Standard Brick & 658 & 24.4 & 16,450 \\
\hline Blanket & & 30 & 7.5 & 1,800 \\
\hline Blanket & & 20 & 6.7 & 1,040 \\
\hline Blanket & & 221 & 27.6 & 8,840 \\
\hline Blanket & $18 \times 24$ blanket & 264 & 33.0 & 10,560 \\
\hline Pb-Other & hollow lead pipe & 1 & 1.3 & 450 \\
\hline Shot & Lead Shot in Boxes & 23 & 1.3 & 460 \\
\hline & & Quarter Total: & 101.7 & 39,600 \\
\hline
\end{tabular}

\section{Lead Items Shipped:}

\begin{tabular}{|c|c|c|c|c|}
\hline Type & Description & Count & Volume (ft3) & Weight (lbs) \\
\hline Blanket & & 3 & 0.4 & 120 \\
\hline Blanket & $18 \times 24$ blanket & 52 & 6.5 & 2,080 \\
\hline Blanket & white vinyl blanket & 1 & 0.1 & 40 \\
\hline & & Quarter Total: & 7.0 & 2,240 \\
\hline
\end{tabular}

Note: None.

\section{Quarter-2}

Lead Items Received:

\begin{tabular}{|c|c|c|c|c|}
\hline Type & Description & Count & Volume (ft3) & Weight (lbs) \\
\hline Blanket & & 50 & 16.7 & 2,600 \\
\hline Pb-Other & Blue Pipe Wrap from NRF & 7,131 & 99.0 & 64,179 \\
\hline & & Quarter Total: & 115.7 & 66,779 \\
\hline
\end{tabular}

\section{Lead Items Shipped:}

\begin{tabular}{|c|c|c|c|c|}
\hline Type & Description & Count & Volume (ft 3 ) & Weight (lbs) \\
\hline Blanket & & 30 & 7.5 & 1,800 \\
\hline Blanket & & 20 & 6.7 & 1,040 \\
\hline Blanket & & 67 & 8.4 & 2,680 \\
\hline Blanket & $18 \times 24$ blanket & 107 & 13.4 & 4,280 \\
\hline & & Quarter Total: & 35.9 & 9,800 \\
\hline
\end{tabular}

Note: None. 


\section{CLF Quarterly/Annual Report for 1994}

Quarter-3

Lead Items Received:

\begin{tabular}{|c|c|c|c|c|}
\hline Type & Description & Count & Volume (ft3) & Weight (lbs) \\
\hline Brick & Standard Brick & 1,000 & 37.0 & 25,000 \\
\hline Pb-Other & Blue Pipe Wrap from NRF & 150 & 2.1 & 1,350 \\
\hline Blanket & $18 \times 24$ blanket & 10 & 1.2 & 400 \\
\hline Cask & & 1 & 0.8 & 500 \\
\hline Blanket & white vinyl blanket & 50 & 4.2 & 2,000 \\
\hline
\end{tabular}

\section{Lead Items Shipped:}

\begin{tabular}{|c|c|c|c|c|}
\hline Type & Description & Count & Volume (ft3) & Weight (lbs) \\
\hline Brick & Standard Brick & 30 & 1.1 & 750 \\
\hline Shot & Lead Shot in Boxes & 11 & 0.6 & 220 \\
\hline & & Quarter Total: & 1.7 & 970 \\
\hline
\end{tabular}

Note: None.

\section{Quarter-4}

Lead Items Received:

\begin{tabular}{|c|c|c|c|c|}
\hline Type & Description & Count & Volume (ft3) & Weight (lbs) \\
\hline Brick & Standard Brick & 12,345 & 457.2 & 308,625 \\
\hline Blanket & & 222 & 27.7 & 8,880 \\
\hline & & Quarter Total: & 485.0 & 317,505 \\
\hline
\end{tabular}

Lead Items Shipped:

No Lead Items Shipped

Note: None. 


\section{CLF Quarterly/Annual Report for 1994}

\section{Annual Summary}

\section{Lead Items Received:}

\begin{tabular}{|c|c|c|c|c|}
\hline Type & Description & Count & Volume (ft3) & Weight (lbs) \\
\hline Brick & Standard Brick & 14,003 & 518.6 & 350,075 \\
\hline Blanket & & 30 & 7.5 & 1,800 \\
\hline Blanket & & 70 & 23.3 & 3,640 \\
\hline Blanket & & 443 & 55.4 & 17,720 \\
\hline $\mathrm{Pb}$-Other & Blue Pipe Wrap from NRF & 7,281 & 101.1 & 65,529 \\
\hline Blanket & $18 \times 24$ blanket & 274 & 34.2 & 10,960 \\
\hline Cask & & 1 & 0.8 & 500 \\
\hline Blanket & white vinyl blanket & 50 & 4.2 & 2,000 \\
\hline Pb-Other & hollow lead pipe & 1 & 1.3 & 450 \\
\hline Shot & Lead Shot in Boxes & 23 & 1.3 & 460 \\
\hline & & & 748 & 453,134 \\
\hline
\end{tabular}

\section{Lead Items Shipped:}

\begin{tabular}{|c|c|c|c|c|}
\hline Type & Description & Count & Volume (ft3) & Weight (lbs) \\
\hline Brick & Standard Brick & 30 & 1.1 & 750 \\
\hline Blanket & & 30 & 7.5 & 1,800 \\
\hline Blanket & & 20 & 6.7 & 1,040 \\
\hline Blanket & & 70 & 8.7 & 2,800 \\
\hline Blanket & $18 \times 24$ blanket & 159 & 19.9 & 6,360 \\
\hline Blanket & white vinyi blanket & 1 & 0.1 & 40 \\
\hline Shot & Lead Shot in Boxes & 11 & 0.6 & 220 \\
\hline & & & 45 & 13,010 \\
\hline
\end{tabular}

Note: None. 
INEL-94/0237

Rev. 0

\section{APPENDIX C: UNIQUELY IDENTIFYING LEAD TYPES}

C-1 
The purpose of this Appendix is to provide guidelines and suggestions on identifying lead types for the Clean Lead Facility (CLF) Inventory System and to provide inventory management suggestions. The process ultimately used should be consistent with the design of the CLF database system and be approved by the CLF facility manager.

A unique field, in database terminology, is a field that has no duplicate values. The purpose of uniquely identifying the lead types is two-fold. First, the lead types need to be identified so they may be accounted for and inventoried. If duplicate lead types existed, then the facility would be difficult to inventory and would result in erroneous results. Second, the database system utilizes a unique field to categorize and sort the records. The combination of the two provides for a consistent and accurate inventory system, both from the perspective of managing the lead and from operating the database.

It was previously explained that the CLF database system design was similar to a grocery store inventory. The grocer is concerned about the quantity of items exchanged and not necessarily on which item was exchanged. The barcode on an item, for example, a $16 \mathrm{oz}$. can of Del Monte brand peas, is the unique identifier for all cans of peas of that type. A different barcode is on the another brand and size of canned peas, or any other particular item in the store. When the cans of peas are bought, the barcode from one item may be scanned into a computer for inventory purposes and the number of cans is entered. The grocer may use a computer to determine how many cans of that particular food item is in inventory. When a consumer buys a quantity of that item, the item (i.e. the barcode) is once again scanned into the computer at the checkout stand but this time the quantity is subtracted from inventory. The grocer can use the computer again to determine how many items are remaining. At some point in time, the grocer may reconcile the cans of peas on the shelves by conducting a physical inventory of those cans of peas and compare that number with the number the computer has registered. The CLF lead inventory database was designed around the same principal.

If the lead type contains a barcode, then that identification may be used. If barcodes are used, then each lead type should be verified that it contains the exact same barcode id. A lead item may contain a barcode if it was given a barcode by a manufacturer or if a program used a barcode to identify a lead item, like a cask. It is suggested that barcodes only be used for non-standard items that already contain a barcode. Generally, most lead items do not contain barcodes so the user must assign a number or id that can be used for identification.

The unique number should be consice, easily recognizable by the inventory users, and simple to use. Sequential numbers are not suggested to be used since they generally have no distinguishing denotation. Symbols, other than a hyphens, should be avoided. The following table shows a suggested unique numbering scheme. Note that the general description of the item is encoded into the unique id of these examples.

\begin{tabular}{|l|l|l|l|l|}
\hline Lead Type & Weight & Dimensions & Other Descriptors & -Unique Id Options \\
\hline Blanket & 40 & $12 \times 36 \times 0.5$ in. & White Vinyl Covering & BLN-1236W or BL401236W \\
\hline Brick & 26 & $8 \times 4 \times 2$ in. & Standard Size Brick & BRK-0804 or BRSTD-0804 \\
\hline
\end{tabular}


INEL-94/0237

Rev. 0

\begin{tabular}{|l|l|l|l|l|}
\hline Sheet & 345 & $48 \times 6$ in. & $\begin{array}{l}\text { Manf. by: Lead Inc. } \\
\text { Barcode: pb12345-001 }\end{array}$ & SHE-4806 or pb12345-001 \\
\hline Blanket & 35 & $24 \times 18 \times 0.5$ in. & White Vinyl Covering & BLN-2418W or BL-W-2418 \\
\hline Shot & 20 & $6 \times 6$ in. & $\begin{array}{l}\text { One Can of \#7 shot from } \\
\text { D\&D cleanup work. }\end{array}$ & SHO-0606-7 or SHO-N7-20 \\
\hline
\end{tabular}

In addition to identifying the lead types in the inventory system, the id numbers need to be related to the actual items in inventory. The simplest method of doing this is to stencil with indelible ink on the surface of each item. The standard items, like bricks, may not need to be individually labeled, but they should be organized in a easily identifiable manner. The pallet or bin in which they are stored can be identified or sections of the facility may be segregated with the various lead types that can be placed there. Another alternative is to obtain photographs of the various lead types and place the appropriate label on the picture. The picture may be placed in the facility or in facility procedures or whereever lead shipments are conducted. 
Rev. 0

APPENDIX D: CREATING CUSTOM QUERIES AND REPORTS

D-1 
Before attaching to the Inventory System, you need to be aware of the limitations and precautions associated with attached databases. The user's manual should also be understood before working on an attached database. Although this Appendix gives general instruction on creating ad hoc queries and reports, a knowledge of database design will improve the quality and effectiveness of the queries and reports.

\section{D.1 ATTACHED DATABASES}

To create queries and reports based on the data in the inventory system, an new database needs to be created. The new database will "attach" to the parent database tables and allow you to use the data from the inventory system to answer questions, design queries, or print reports. Using an attached database insures that the data is always the same as the inventory system records and prevents having to maintain two separate sources of the data. The following instructions are intended to aid the user in the creation of an attached database:

1. If the inventory system is being used, select the QUIT button from the main inventory system screen to return to the Microsoft (MS) Access menu. Otherwise, start MS Access by double-clicking on its icon with the mouse and enter your assigned name and password.

2. From the menu bar, select FILE and NEW DATABASE. This will cause a pop-up form to appear, specify a local directory ( usually $\mathrm{C}$ : , or D:), directory path, and file name for the personal ad hoc database. (e.g., C:\ACCESSIMYDATA.MDB) When done, click OK with the mouse. This will open a new database. Ensure the *.MDB extension trails the new database filename.

3. This new database is empty. To see the CLF Inventory System data, the user will need to "attach" to the tables of interest. This is done by selecting File, and Attach Table from the menu bar. Select the MS Access file type and identify the inventory system and its path. The inventory systems path is U:IDATABASE\CLF\CLF.MDB, where $U$ : is the drive the system is installed on.

After selecting the database, a list of Inventory System tables will be displayed. Highlight the table of interested, and press the Attach button. This table will now appear in the new database. Once attached to the table, queries and reports on the data can be run.

\section{D.1.1 Queries in Attached Databases}

A query is a question asked about the data in the inventory system. To make a query, you must define the records to see in the Query window by selecting fields, criteria, and sort order. The Query window is a graphical query-by-example (QBE) tool. Because of its graphical features, the mouse is used to select, drag, and otherwise manipulate the objects in the Query window. A Select Query is the default query created in MS Access. This type of query selects records that meet the criterion specified in the query design. The following instructions explain how to create a select query. Additional information may be found in the MS Access User's Guide, Part 3. 
1. Start MS Access and open an attached database.

2. In the Database window, click on the Query button.

3. Choose the New button. MS Access opens a new Query window and displays the Add Table dialog box.

4. Select the table you want to use in your query and then click on the ADD button with the mouse. MS Access adds your selected table to your query.

Note: If you want to delete a table you have added to the query window, select it with the mouse and press the delete key.

5. If you want, choose another table and then click on the ADD button with the mouse.

6. Click on the CLOSE button with the mouse. MS Access closes the Add Table dialog box.

Note: If you want to add an additional table to your query and you have already closed the Add Table dialog box, you can select the Query menu from the pull down menu and click on the Add Table command to redisplay the Add Table dialog box.

7. In native MS Access tables, the relationships (joins) between tables are maintained. The relationships should also be carried over to the attached database queries. The relationship is defined by a line connecting the various tables. If the relationships are not established when a query is designed, then they should be established at this time in the attached database queries. To create a join between two tables, click and hold the mouse on the field from one table and drag the mouse to the field in the second table. When you release the mouse button over the second field, a line should appear between the two fields of the tables.

There are several types of joins between tables, the default join type which MS Access uses it to match only records that appear in both tables. To change the join type, double click on the join line with the mouse, a dialog box will appear. Select the type of join desired from the choices. Close the dialog box.

A join line connects the two table for the current query only. If you use the same two tables in another query, you will need to join them again.

To delete the join between tables, click on the join line to select it, then press the delete key.

8. To add a field to your query, select a field from the field list and drag it to the first cell in the field row of the QBE grid (located on the lower portion of your screen). When the pointer is over the first cell, release the mouse button. Use the same method to add other fields to the QBE grid field row (from any selected tables). 
9. To look at the records this query will produce, click on the Datasheet View button on the tool bar ( or choose Datasheet from the View menu). To return to Design view, click on the Design View button (or choose Query Design from the View menu).

10. To specify criteria for a query, switch back to Design View, move to the Criteria cell (located in the lower portion of the QBE window) for the field(s) you are going to specify criteria against. Type criteria in the cell that will limit the data and press enter.

11. To sort records, switch back to Design view, and place the cursor in the Sort cell for the field you would like to use for the sort. The pull-down list will allow several options: Ascending, Descending, or Not Sorted. Select the appropriate sort option then select the Datasheet view to see the results of the query.

12. To save a query, choose Save Query from the File menu. Type the name you would like to call your query in the Query Name box. Choose the OK button. MS Access will now save your query. You will be able to see it in the Query listing in the database window. At any time you can re-run the query from the database window by opening the query in the Query listing. The query will automatically run, selecting any new data that has been updated since the last query.

13. To print your query data results, open the query in Datasheet view or select it in the Database window. From the File menu, choose Print. MS Access displays the Print dialog box. Chose the OK button. MS Access will now print your query data results.

You can also create totals queries and cross-tabulation queries. These types of queries are more advanced topics and are not addressed here. For more information on these types of queries, see the MS Access User's Guide. 


\section{D.2 REPORTS}

Instead of printing the results of a query, you can create a report to represent the data in many different formats. Reports allow you to show the "big picture" by grouping data and showing grand totals as well as subtotals.

\section{D.2.1 Creating a Report Using Report Wizard}

MS Access comes with a function which automatically formats fields you select from a table or a query in several predefined formats. This function is known as a Report Wizard. The Report Wizard is the simplest and quickest method of preparing a report. To make a report using the Report Wizard, follow the directions below.

1. In the Database window, click the mouse on the Report button.

2. Choose the New button. MS Access displays the New Report dialog box.

3. Select a table or a query that you have already prepared on which you want to base the report. Choose the Report Wizard button. MS Access displays the first Report Wizard dialog box.

4. Make choices from the Report Wizard dialog box. For example, select the Groups/Totals Report Wizard. The wizard will prompt you to add the fields you want to appear in the report, then select the fields you want to group by (e.g., lead type), group fields by unique values, sort the records based on a field, choose the style of the report, give your report a title, and choose the Print Preview button. (If you want to be able to edit the design of the report, select Design Mode.)

5. MS Access will display a preview of the report. To see the entire page, position the pointer over the report until it changes to a magnifying glass and click the mouse on the report. To return to viewing data, click on the report again.

To navigate within the report when it is magnified: use the scroll bars that appear at the right and bottom of the screen to move around within a page and use the page navigation buttons at the bottom of the window to move between pages.

6. To print the report, choose Print from the File menu. You can also click the mouse on the Print button on the tool bar in Print Preview mode.

7. To save a report, choose Save from the File menu. MS Access displays the Save As dialog box. Type the name you would like to call your report in the Report Name box. Choose the OK button. MS Access saves the report. This name will appear in the Report Menu list. 


\section{D.2.2 Creating a Report in Design View}

The previous section discussed creating and printing reports using the Report Wizard function. You can also create reports in Design View. In Design View you can position Fields and Labels and add graphics to your report. The use of these advanced reporting features is beyond the scope of this document. For further information refer to the MS Access User's Guide, Part 5, Reports. 